\title{
A new species of Bryconops (Teleostei: Characidae) from the rio Madeira basin, Northern Brazil
}

\author{
Juliana M. Wingert and Luiz R. Malabarba
}

\begin{abstract}
A new species of Bryconops is described from a tributary to the rio Madeira in the Amazon basin, State of Rondônia, Brazil. Bryconops piracolina belongs to the subgenus Bryconops by having no teeth or rarely one tooth in the maxilla, and a naked area on cheek between the second and third infraorbitals. The new species is distinguished from all species of this subgenus by the presence of a large black blotch on dorsal-fin base. Furthermore, it is distinguished from all congeners, except $B$. inpai, by possessing the adipose fin entirely black. It differs from $B$. inpai by the lack of humeral spots. It further differs from all species of the subgenus Bryconops, except B. caudomaculatus, by having the last scales of the longitudinal series of scales that bears the lateral line series not pored beyond the end of the hypural plate, and differs from $B$. caudomaculatus by the smaller number of pored lateral line scales (31-36, mean 34.6, vs. 37-43, mean $=40.6$, respectively).
\end{abstract}

Uma nova espécie de Bryconops é descrita para um tributário do rio Madeira na bacia do rio Amazonas, Brasil. Bryconops piracolina pertence ao subgênero Bryconops por não possuir dentes ou raramente apresentar apenas um dente na maxila, e por possuir uma área nua na face entre o segundo e terceiro infraorbitais. A espécie nova se distingue de todas as espécies do subgênero Bryconops pela presença de uma grande mancha negra na base da nadadeira dorsal. Além disto, difere de todas as espécies do gênero, exceto $B$. inpai, por possuir a nadadeira adiposa inteiramente preta. Difere de $B$. inpai pela ausência de manchas umerais. Difere de todas as espécies de Bryconops, exceto B. caudomaculatus, por possuir as últimas escamas da série longitudinal de escamas da linha lateral sem poros além da terminação da placa hipural e difere de $B$. caudomaculatus pelo menor número de escamas com poros da linha lateral (31-36, média 34,6 vs. 37-43 média, 40,6; respectivamente).

Key words: Bryconops caudomaculatus, Neotropical, Systematics, Taxonomy.

\section{Introduction}

Bryconops Kner, 1858 is a relatively small cis-Andean genus of the Characidae including 18 valid species (Lima et al., 2003; Chernoff \& Machado-Allison, 2005) distributed in the coastal rivers of northern Brazil and Guyana, and in the Orinoco, Amazonas, Tocantins, Paraguay, and São Francisco river basins. The genus has been considered relatively basal in the Characidae in possessing a supraorbital bone that is absent in the representatives of most small-sized characids (Malabarba \& Weitzman, 2003). Such a basal position was further supported by Mirande (2010) who listed fourteen synapomorphies in addition to the lack of a supraorbital bone in defining a large clade containing most small-sized characids and excluding Bryconops. The species in the genus are currently divided among two subgenera, Bryconops and Creatochanes Günther, 1864. These were treated as monophyletic by Chernoff \& Machado-Allison (1999) and in subsequent papers. In this paper we describe a new species of Bryconops, subgenus Bryconops, as defined by Chernoff $\&$ Machado-Allison $(1999,2005)$ from the rio Madeira basin, rio Amazonas drainage, in the State of Rondônia, Brazil.

\section{Material and Methods}

Examined specimens belong to: Academy of Natural Sciences, Philadelphia, (ANSP), Instituto Nacional de Pesquisas da Amazônia, Manaus (INPA), Museu de Ciências e Tecnologia da Pontifícia Universidade Católica do Rio Grande do Sul, Porto Alegre (MCP), Museu Nacional, Rio de Janeiro (MNRJ) and Museu de Zoologia da Universidade de São Paulo, São Paulo (MZUSP). Comparisons to species not listed in comparative material were based on the literature. Measurements were calculated as interlandmark distances based on 14 homologous landmarks acquired with a digital camera and extracted using the software LMDis (by R. E. Reis, 1996). Counts were taken according to Malabarba \& Bertaco (1999). The landmarks were the same described by

Universidade Federal do Rio Grande do Sul, Programa de Pós-Graduação em Biologia Animal, Departamento de Zoologia, Av. Bento Gonçalves 9500, 91501-970 Porto Alegre, RS, Brazil, juwingert@yahoo.com.br; malabarb@ufrgs.br 
Machado-Allison et al. $(1993,1996)$ for Bryconops, except for the adipose fin and posterior margin of opercle. We followed Malabarba \& Bertaco (1999) in marking the adipose position at the posterior termination of its base instead of anterior origin, and opercle at the uppermost termination of the branchial opening instead of the most posteriormost point of its margin because these are more precise and homologous landmarks. Drawings were made from cleared and stained specimens (c\&s; Taylor \& Van Dyke, 1985), using a stereomicroscope with a camara lucida attachment. In the description the parentheses correspond to the number of specimens examined and asterisks indicates the value observed in the holotype.

\section{Results \\ Bryconops piracolina, new species \\ Figs. 1-4}

Holotype. MCP 44796, male, 69.0 mm SL, Brazil, Rondônia, Vilhena, Igarapé Piracolina (rio Madeira basin), about $6 \mathrm{~km} \mathrm{~W}$ of Vilhena, near highway BR-364, 1243'33"S 60¹1'34”W, 14 Jul 2004, R. E. Reis, P. A. Buckup, A. R. Cardoso \& E. H. L. Pereira. Paratypes. Brazil: Rondônia: MCP 41504, 1 male (c\&s, $51.1 \mathrm{~mm}$ SL), 4 females (1 c\&s, $35.0 \mathrm{~mm} \mathrm{SL}$ ), 29.3-71.3 mm SL, MZUSP 105731, 2 females ( 32.9 and $40.1 \mathrm{~mm} \mathrm{SL}$ ), collected with holotype.

Diagnosis. Bryconops piracolina belongs to the subgenus Bryconops in having no teeth or rarely one tooth on the maxilla and a naked area on the cheek between the second and third infraorbitals. It is distinguished from all species of this subgenus by the pigmentation of the dorsal fin with a large black blotch extending from near the dorsal-fin base distally for approximately one half the length of most dorsal-fin rays, in contrast to the dorsal fins of congeneres that are slightly pigmented with scattered chromatophores. Bryconops piracolina furthermore is distinguished from all congeners, except $B$. inpai Knöppel, Junk \& Géry, 1968, by possessing an entirely black adipose fin. It differs from $B$. inpai by its lack of humeral spots. It further differs from all species of the subgenus Bryconops, except for B. caudomaculatus (Günther, 1864), by having the last scales of the longitudinal series of scales that bears the lateral line series not pored beyond the end of the hypural plate. Bryconops piracolina differs from $B$. caudomaculatus by the number of pored lateral line scales (31-36, mean 34.6, $\mathrm{n}=8, v s$. 37-43, mean $=40.6, \mathrm{n}=$ 101 , respectively).

Description. Morphometric data summarized in Table 1. Largest specimen $71.3 \mathrm{~mm}$ SL. Body shape compressed, greatest body depth located just anterior to dorsal-fin origin. Dorsal body profile convex from margin of upper lip to region near nares; straight from that point to end of supraoccipital spine; convex from this point to dorsal-fin origin. Straight and posteroventrally-aligned along dorsal-fin base; straight and convex from end of dorsal-fin base to adipose fin and concave from that point to insertion of dorsal procurrent caudal-fin rays. Ventral body profile convex from lower jaw to pelvic-fin origin; straight from this point to anal-fin origin. Straight and posterodorsally-aligned along anal-fin base; concave from posterior end of anal-fin base to ventral procurrent caudal-fin rays. Caudal peduncle slightly longer than deep. Dorsal-fin origin situated anterior to vertical through pelvic-fin origin and near middle of body.

Cheek area between second and third infraorbitals naked ventrally; third infraorbital moderately developed, not reaching preopercle ventrally or at angle. Supraorbital bone

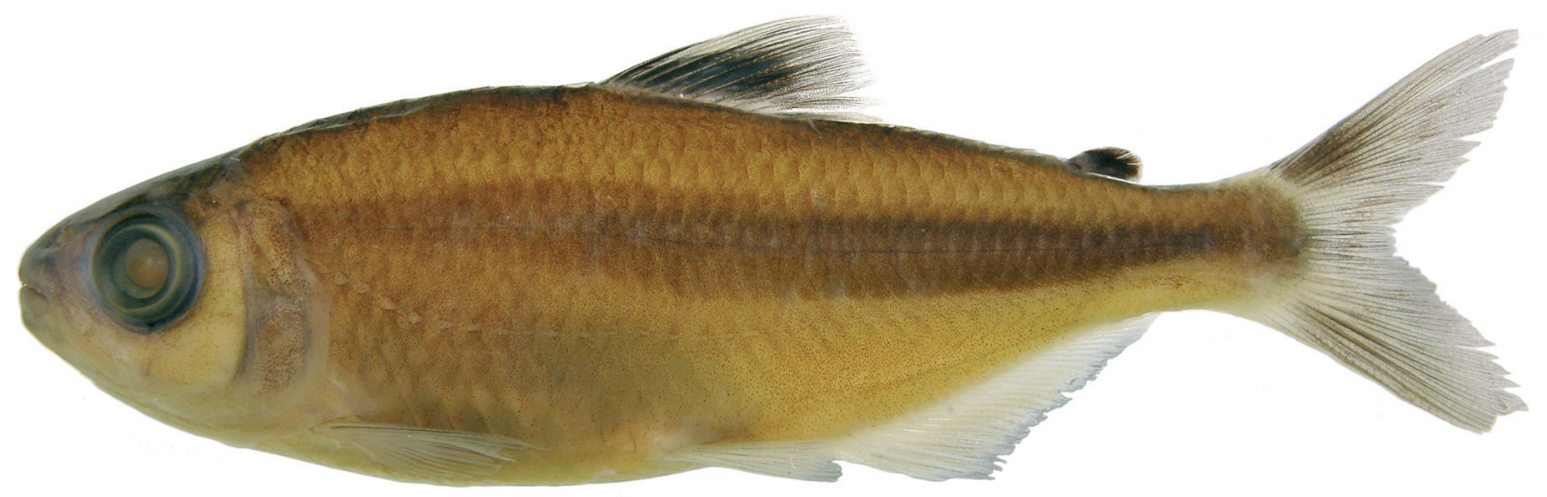

Fig. 1. Bryconops piracolina, MCP 44796, holotype, male, $69.0 \mathrm{~mm} \mathrm{SL}$; Brazil, Rondônia, Igarapé Piracolina, tributary of rio Madeira, rio Amazonas drainage, about $6 \mathrm{~km}$ West of Vilhena. 


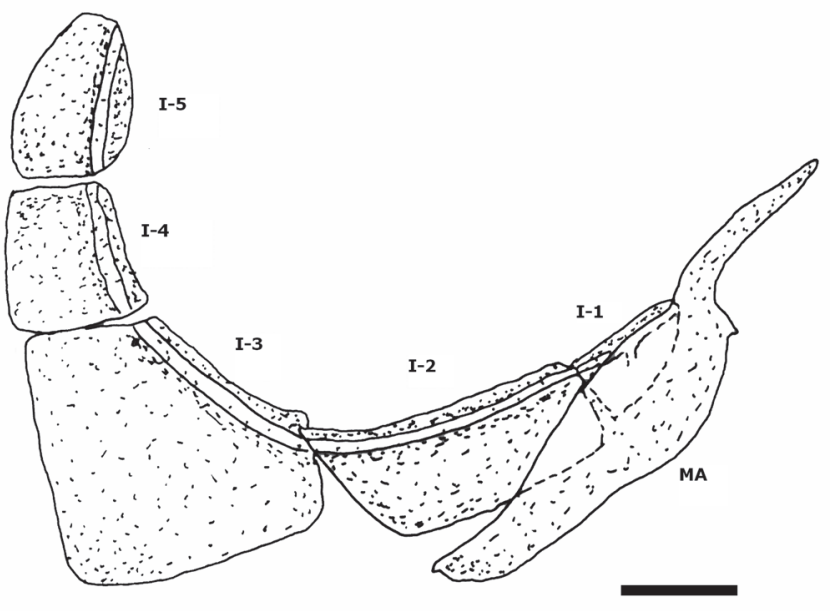

Fig. 2. Maxilla and infraorbitals 1-5 of Bryconops piracolina, right side, MCP 41504, paratype, $35.0 \mathrm{~mm}$ SL, c\&s. Abreviations: I- 1 to I-5= Infraorbitals 1 to 5 ; $\mathrm{MA}=$ maxilla. Scale bar $=1 \mathrm{~mm}$.

present. Eyes large than shout length. Adipose ocular membrane well developed. Maxilla not extending posteriorly to posterior margin of second infraorbital (Fig. 2) and not reaching vertical through middle of orbit. Mouth terminal,

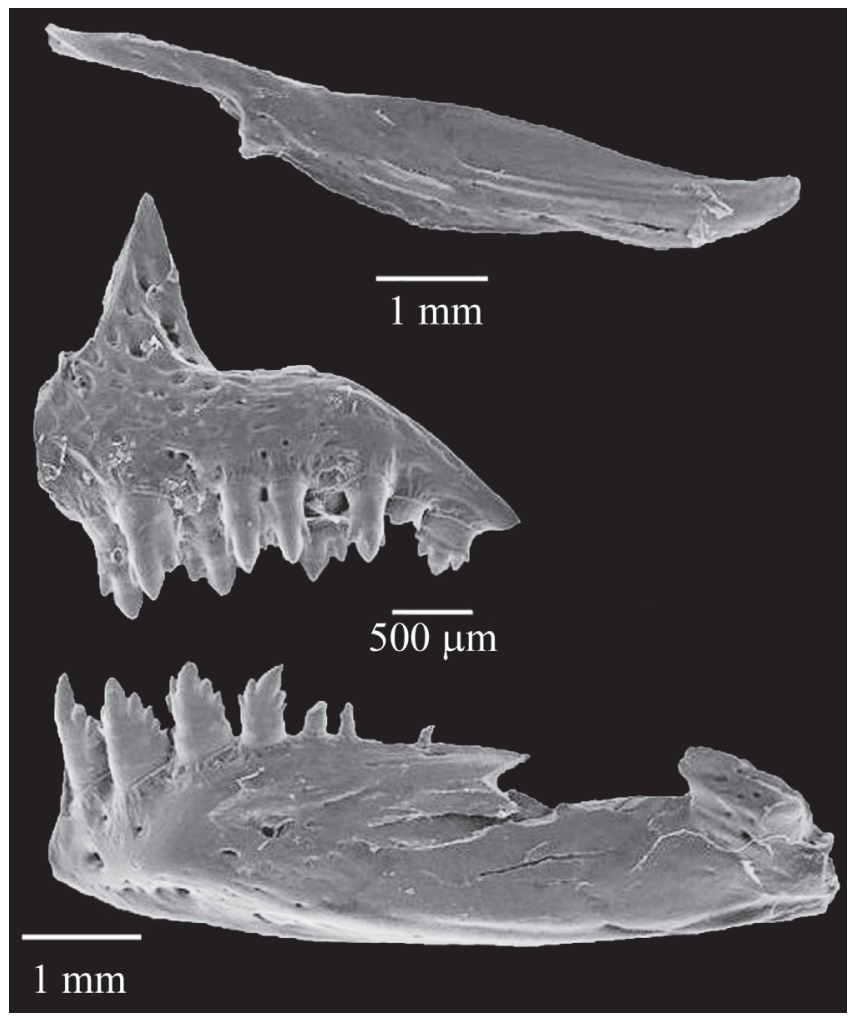

Fig. 3. Bryconops piracolina, MCP 41504, paratype, 51.11 $\mathrm{mm}$ SL c\&s. Scanning electron microscope photograph of left side of maxilla (top), premaxilla (middle), and lower jaw (bottom). Dorsal portion of dentary partially broken. premaxilla slightly longer than lower jaw. Premaxilla with two tooth rows, with central cusp of all teeth more developed than remaining cusps; outer row with 3(2) or 4(6) tricuspid teeth; inner row 5 teeth with 3 to 5 cusps. Maxilla with $0(7)$ or 1(1) tricuspid teeth. Dentary with 4 large teeth with 5 to 7 cusps, followed by 4 smaller conical teeth (Fig. 3 ).

Dorsal-fin rays ii, $9 *(8)$. Posterior margin of dorsal-fin straight to slightly convex, with first and second branched rays longest. Length of first unbranched dorsal-fin ray less than half length of second unbranched ray. Adipose-fin origin approximately at vertical through base of nineteenth to twenty-first anal-fin branched rays. Pectoral-fin rays i,10(3), $11^{*}(4)$, or $12(1)$. Tip of pectoral fin not reaching pelvic-fin origin. Pelvic-fin rays: i, $7 *(8)$. Pelvic fin originating at vertical through middle of dorsal-fin base, reaching and sometimes extending beyond anal-fin origin. Anal-fin rays iv-v,21(3), 22(2), 23(2), or 24*(1), first unbranched ray sometimes visible only in cleared and stained specimens. Anal-fin origin located posterior to vertical through base of last dorsal-fin ray. Distal margin of anal-fin falcate in juveniles with last unbranched ray and second and third branched rays slightly longer than others, but nearly straight in adults. Caudal-fin rays $\mathrm{i}, 8,9, \mathrm{i}$ principal rays (8). Lobes of caudal fin unequal with lower lobe longer than upper lobe. Dorsal procurrent caudal-fin rays 11 , ventral procurrent caudal-fin rays 11 .

Total scales in longitudinal series containing lateral line scales 38(2), 39(1), 40*(1), 41(1), or 42(2). Pored lateral line scales $31(1), 34(2), 35^{*}(2)$, or 36(3). Scale rows between lateral line and dorsal-fin origin $6(2)$ or $7 *(6)$. Scale rows between lateral line and pelvic-fin origin $5 *(7)$. Predorsal scales $8(1)$ or $9 *(6)$ and arranged in regular series. Scale rows around caudal peduncle $10^{*}(4)$ or 11(3). Scales along anal fin base 3 or 4 in single series. Few scales covering base of caudal-fin lobes. Precaudal vertebrae $18^{*}(2)$; caudal vertebrae 22(1), 24(1); total vertebrae 40(1), 42(1). First dorsal-fin pterygiophore located between tenth and eleventh vertebrae. Supraneurals 7(2), large, inserted between neural spines.

Gill rakers of first gill arch 14 or 15: hypobranchial 2(2), ceratobranchial 6(2), between epibranchial cartilage and ceratobranchial 1(2), epibranchial 5(1), 6(1). Branchiostegal rays 4: 3(2) on ceratohyal and 1(2) on epihyal. Gill rakers setiform.

Color in alcohol. Overall ground coloration of body dusky brown. Dorsal profile of head, snout, and upper jaw with scattered black chromatophores. Opercle with chromatophores scattered over dorsolateral region. Infraorbitals, opercular and gular regions pale yellow. Heavily pigmented black mid lateral stripe extending from upper margin of opercle to caudal-fin base. Stripe narrow anteriorly and progressively expanding from head to under dorsal fin; occupying almost half distance between lateral line and dorsal contour of body in region between dorsal and adipose fins and then becoming narrower along caudal peduncle. Scales on dorsal and dorsolateral portions of body with black chromatophores more concentrated on their edges. Scales 
Table 1. Morphometric data of holotype $(\mathrm{H})$ and paratypes $(n=7)$ of Bryconops piracolina. Holotype is not included in the range and mean. $\mathrm{SD}=$ standard deviation.

\begin{tabular}{lcccc}
\hline & H & Range & Mean & SD \\
\hline Standard length (mm) & 69.0 & $29.3-71.3$ & 38.7 & - \\
& Percents of Standard Length & & & \\
Pred orsal length & 49.7 & $48.7-51.4$ & 50.1 & 0.95 \\
Pectoral-fin length & 27.8 & $26.9-31.8$ & 30.5 & 1.66 \\
Pelvic-fin length & 54.9 & $53.1-58.0$ & 56.1 & 1.69 \\
Anal-fin length & 67.9 & $66.6-69.2$ & 67.7 & 1.18 \\
Dorsal-fin bas e length & 16.1 & $13.4-14.6$ & 14.0 & 0.45 \\
Dorsal origin - Pectoral origin & 35.9 & $31.0-35.9$ & 32.8 & 1.58 \\
Dorsal origin - Pelvic origin & 30.0 & $25.8-29.7$ & 26.7 & 1.34 \\
Dorsal terminus - Anal origin & 27.2 & $21.9-26.5$ & 23.3 & 1.50 \\
Dorsal terminus - Pelvic origin & 28.9 & $23.9-29.3$ & 25.1 & 1.88 \\
Adipose terminus - Hypural joint & 14.1 & $12.6-15.3$ & 13.9 & 0.84 \\
Pectoral origin - Pelvic origin & 28.4 & $25.0-27.7$ & 26.8 & 1.04 \\
Anal-fin base length & 24.2 & $21.2-24.9$ & 23.1 & 1.37 \\
Length of caudal peduncle & 14.9 & $14.1-16.1$ & 14.8 & 0.84 \\
Dorsal origin - Anal origin & 35.2 & $29.5-33.5$ & 30.9 & 1.26 \\
Adipose terminus - Base of last anal-fin ray & 12.5 & $10.3-12.2$ & 11.1 & 0.63 \\
Maxillary length & 13.3 & $12.8-16.5$ & 15.7 & 1.33 \\
Snout length & 7.2 & $7.0-8.9$ & 8.2 & 0.62 \\
Horizontal orbit diameter & 7.8 & $7.7-11.3$ & 10.4 & 1.30 \\
Head len gth & 21.4 & $20.4-27.1$ & 25.3 & 2.40 \\
& \multicolumn{1}{c}{ Percents of Head Length } & & & \\
Tip of snout - Tip of su praoccipital spine & 114.2 & $108.0-120.9$ & 111.7 & 4.50 \\
Maxilla - Pectoral ori gin & 72.8 & $58.9-73.4$ & 64.1 & 5.05 \\
Maxilla - Posterior margin of opercle & 88.8 & $79.2-85.4$ & 81.3 & 2.64 \\
Anterior margin of orbit - maxilla & 54.2 & $44.0-55.1$ & 49.3 & 3.67 \\
Posterior margin of orbit - opercle & 33.5 & $26.4-31.1$ & 28.2 & 1.78 \\
Maxillary length & 61.9 & $59.1-67.1$ & 62.2 & 2.55 \\
Snout length & 33.5 & $30.0-34.5$ & 32.4 & 1.62 \\
Horizontal orbit diameter & 36.4 & $37.8-42.6$ & 41.0 & 1.64 \\
\hline & & & &
\end{tabular}

dusky with chromatophores less concentrated ventrally. Pored lateral-line scales slightly more pigmented than surrounding scales, resulting on lateral line being readily visible posteriorly to vertical trough posterior portion of dorsal fin and in some specimens, almost to posterior limit of lateral line. No humeral blotch. Many black chromatophores scattered on portion of body between lateral line and anal-fin base. Dorsal fin with black blotch extending from near dorsal-fin base to mid length of dorsal-fin rays; distal margin of dorsal fin lighter. Adipose fin black. Anal, pectoral and pelvic fins with scattered black chromatophores. Caudal fin rather dark, with small more lightly pigmented areas near base of dorsal and ventral lobes. Upper lobe of caudal fin with darkened proximal blotch reaching dorsal border of fin (Fig. 1).

Sexual dimorphism. Males bear hooks on the anal and pelvicfin rays. Anal-fin hooks are small and spine-like and distributed along only the distal half of the fin rays up to the eleventh the branched ray. Number of hooks decreasing from last unbranched ray to eleventh branched ray (Fig. 4). Pelvicfin hooks larger and spine-like; present on unbranched ray and first five branched rays.

Distribution. Bryconops piracolina is known from its type locality, Igarapé Piracolina, a tributary to the rio Madeira, rio Amazonas drainage, about $6 \mathrm{~km}$ west of Vilhena, Rondônia, Brazil (Fig. 5).
Etymology. The specific epithet name piracolina is given in allusion to its type locality, Igarapé Piracolina. A noun in apposition.

\section{Discussion}

Bryconops piracolina shares the three synapomorphies proposed by Chernoff \& Machado-Allisson (1999) for Bryconops: the ventral edge of the maxilla curves sharply almost $90^{\circ}$ posteriorly, extending to or beyond the quadrate socket of the angulo articular; the antorbital bears a well developed infraorbital sensory canal; and the supraorbital sensory canal extends onto nuchal scales. Bryconops piracolina further belongs to the subgenus Bryconops as recognized by Chernoff \& Machado-Allison (2005) based on the reduction in the ossification and denticulation of the gill rakers and the lack of teeth or presence of only a single tooth on the maxilla. The new species further lacks the synapomorphies proposed by Chernoff \& Machado-Alisson (1999) for the subgenus Creatochanes, including the posterior extension of the maxilla reaching to the junction between the second and third infraorbitals ( $v s$. not reaching in $B$. piracolina), and the second infraorbital contacting the third infraorbital without an intervening naked area on the cheek ( $v s$. not contacting along the half ventral portion of the adjoining margins of the second and third infraorbitals and leaving a naked area between them in B. piracolina). Chernoff $\&$ Machado-Allison (2005) listed six species in the subgenus Bryconops: B. alburnoides Kner, 1858, B. caudomaculatus, B. magoi Chernoff \& Machado-Allison, 2005, B. collettei Chernoff \& Machado-Allison, 2005, B. disruptus MachadoAllison \& Chernoff, 1997, and B. durbini (Eigenmann, 1908). Among the species of the subgenus Bryconops, B. piracolina shares only with $B$. caudomaculatus the reduced lateral line reaching the caudal peduncle but not extending beyond the hypural plate (see Chernoff \& Machado-Allison, 2005: fig. 2A). Bryconops caudomaculatus has the largest distribution on the genus. We examined 121 specimens from several Amazon and Orinoco basin tributaries and found the pored lateral line scale count in B. caudomaculatus (37-43, mean $40.6, \mathrm{n}=101)$ not overlapping that of B. piracolina $(31-36$, mean $34.6, \mathrm{n}=8$ ).

Comparative material. Bryconops affinis. Brazil. INPA 1840 (3, 108.0-118.8 mm SL), Amazonas, Manaus, igarapé Acará, Reserva Adolfo Ducke. MCP 30585 (7, 48.5-64.2 mm SL), Mato Grosso, Vera, rio Tartaruga, road between Vera and Feliz Natal, $20 \mathrm{~km} \mathrm{NE}$ of Vera. Bryconops alburnoides. Brazil. MCP 42127 (3, 131.7-144.4 $\mathrm{mm} \mathrm{SL}$ ), Amazonas, Humaitá, rio Ipixuna at Porto Alegre beach, $c a$. $7.6 \mathrm{~km} \mathrm{~W}$ of BR-319. Bryconops caudomaculatus. Brazil. MCP 42995 (6, 34.8-50.5 mm SL), Amapá, Laranjal do Jari, córrego Santa Rosa. MCP 41503 (18, 44.6-66.3 mm SL), Amazonas, Humaitá, Igarapé about $68 \mathrm{~km}$ E of rio Madeira basin, on Transamazônica highway. MCP 30846 (7, 33.5-47.3 mm SL), Mato Grosso, Tapurah, rio Arinos, at ferry boat between Nova Maringá and Tapurah. MCP 30861 (10, 39.5-63.5 mm SL), Mato Grosso, São José do Rio Claro, rio Claro or rio Água Verde, about $12 \mathrm{~km} \mathrm{SE} \mathrm{of} \mathrm{São} \mathrm{José} \mathrm{do} \mathrm{Rio}$ 


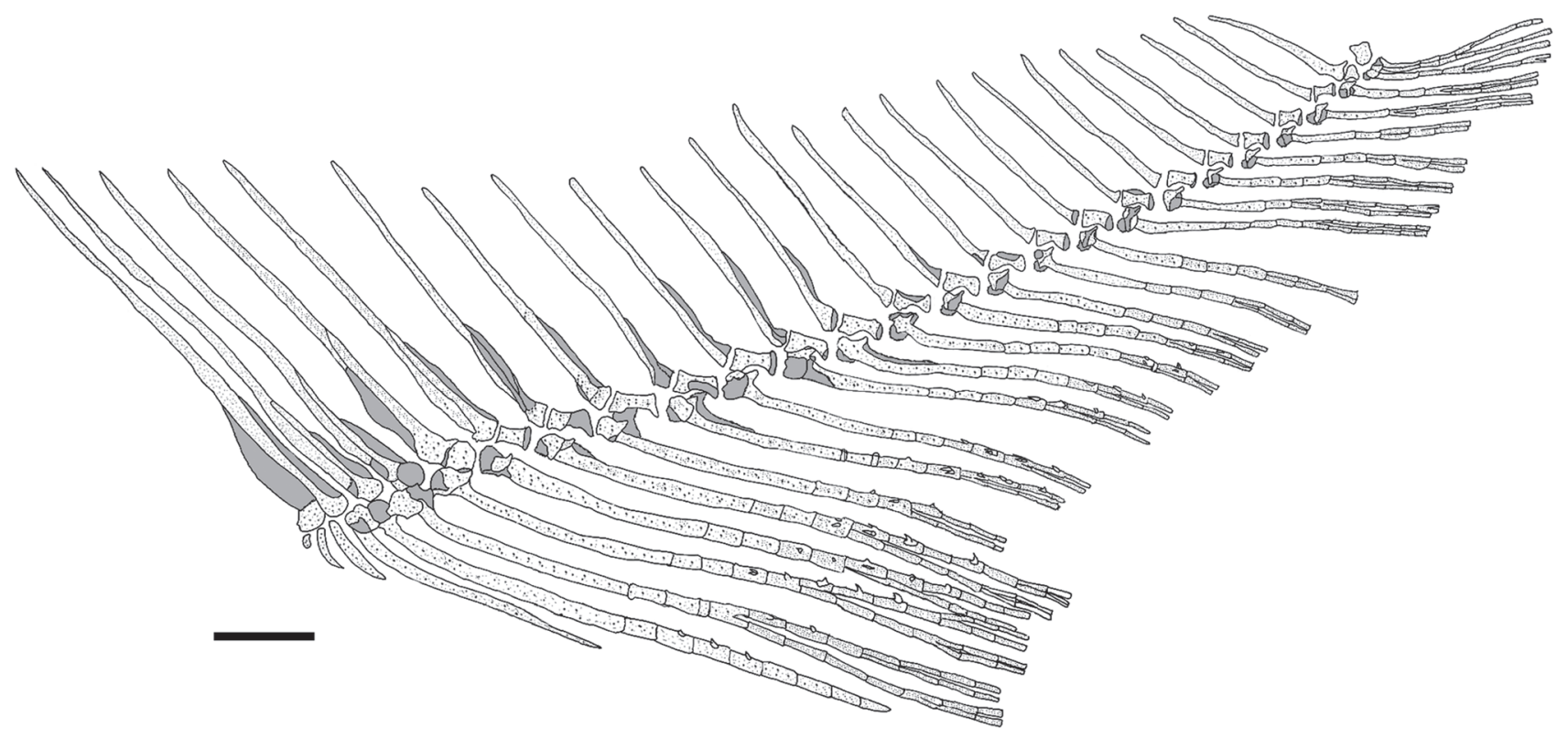

Fig. 4. Anal-fin rays of Bryconops piracolina, male, MCP 41504, paratype, $51.11 \mathrm{~mm}$ SL, c\&s. Left side, anterior to left. Small hooks on the anal fin present only on the distal half of the last unbranched ray up to the eleventh branched anal-fin ray. Scale bar $=1 \mathrm{~mm}$.

Claro, on MT-010 toward Diamantino. MCP 30900 (10, 32.9-44.4 mm SL), Mato Grosso, Sinop, córrego Maria ou Quinze, on road BR-163 about $23 \mathrm{~km}$ N of Sinop. MNRJ 23458 (8, 67.4-76.6 mm SL), Mato Grosso, Sinop, ribeirão Selma, Teles Pires basin, BR163 N of Sinop. MCP 34192 (6, 38.9-55.9 mm SL), Mato Grosso, ribeirão Cascalheira, córrego Gengibre, rio São João and rio das Mortes, on road to Vila Berrante. MCP 42325 (1, 79.0 mm SL), córrego Cachoeirinha, on tributary of rio Claro subbasin, rio Araguaia drainage, Montes Claros de Goiás. MCP 22958 (7, 44.3-77.3 mm SL), Pará, Igarapé Curupuré, on road to Moju/Acará, tributary of rio Acará. MCP 22989 (8, 30.3-50.8 mm SL), Pará, Tomé Açu, creek on road to Tomé Açu/Moju, about $27 \mathrm{~km} \mathrm{~W}$ of Tomé Açu,

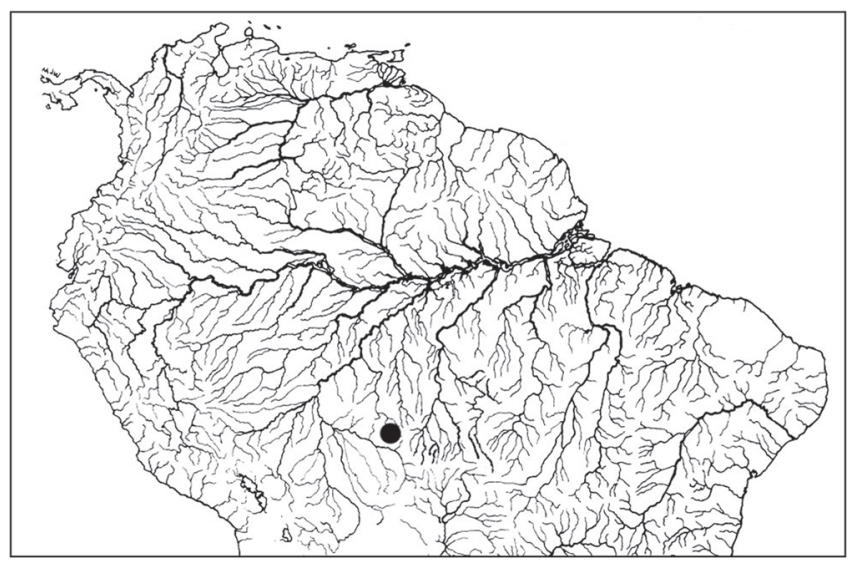

Fig. 5. Central and Northern South America, showing the collection site of Bryconops piracolina, in the rio Madeira drainage. tributary of rio Acará. MNRJ 33266 (6, 51.5-64.6 mm SL), Pará, Novo Progresso, bank of rio Jamanxim, $3 \mathrm{~km}$ from BR-163. MNRJ 33377 (7, 48.9-75.8 mm SL), Pará, Novo Progresso, small stream of Arraias, Jamanxim subbasin, bridge on BR-163. MNRJ 33379 (4, 32.9-42.3 mm SL), Pará, Trairão, rio Jamanxim drainage, BR-163, $5.8 \mathrm{~km}$ NE of Vila de Caracolovia. Venezuela. MCP 17457 (3, 34.9-61.6 mm SL), Amazonas, río Atacavi $30 \mathrm{~km}$ from the confluence with río Atabapo, 3 Nov 1989, L. Nico. Bryconops giacopinni. Brazil. UFRGS 10375 (18, 58.3-74.4 mm SL), Amazonas, Manaus, Balneário Adão e Maria, BR-174. UFRGS 10368 (10, 35.5-61.9 $\mathrm{mm}$ SL), Amazonas, Manaus, igarapé Tarumã-Açú, BR-174. Bryconops inpai. Brazil. ANSP 112213 (2, paratypes, 128.5-164.5 $\mathrm{mm}$ SL), Amazonas, Manaus, lower rio Negro region, igarapé Barro Branco, a brook in the "Reserva Ducke" (INPA) about $30 \mathrm{~km}$ from Manaus. Bryconops melanurus. Brazil. MNRJ 20922 (6, 99.1$118.2 \mathrm{~mm} \mathrm{SL}$ ), Amapá, Macapá, rio Maruanum (tributary at right margin of rio Matapi), BR-156. INPA 10707 (7, 69.7-73.9 mm SL), Amapá, rio Amapá Grande, Cachoeira Grande.

\section{Acknowledgments}

For loan of specimens we thank L. Py-Daniel (INPA), C. A. S. Lucena and Z. M. S. Lucena (MCP), P. A. Buckup (MNRJ), and O. Oyakawa (MZUSP). We thank T. P. Carvalho for the critical review of the manuscript and Centro de Microscopia e Microanálises - CEEM, UFRGS for the SEM preparations. Type specimens were collected during an expedition financed by the All Catfish Species Inventory, supported by the National Science Foundation (NSF-DEB 0315963). LRM research is supported by CNPq (303785/2007$1 ; 479412 / 2008-1)$. 


\section{Literature Cited}

Chernoff, B. \& A. Machado-Allison. 1999. Bryconops colaroja and $B$. colanegra, two new species from the Cuyuní and Caroní drainages of South America (Teleostei: Characiformes). Ichthyological Exploration of Freshwaters, 10: 355-370.

Chernoff, B. \& A. Machado-Allison. 2005. Bryconops magoi and Bryconops collettei (Characiformes: Characidae), two new freshwater fish species from Venezuela, with comments on $B$. caudomaculatus (Günther). Zootaxa, 1094: 1-23.

Lima, F. C. T., L. R. Malabarba, P. A. Buckup, J. F. P. Silva, R. P. Vari, A. Harold, R. C. Benine, O. T. Oyakawa, C. S. Pavanelli, N. A. Menezes, C. A. S. Lucena, M. C. S. L. Malabarba, Z. M. S. Lucena, R. E. Reis, F. Langeani, L. Casatti, V. A. Bertaco, C. L. R. Moreira \& P. H. F. Lucinda. 2003. Genera incertae sedis in Characidae. Pp. 134-141. In: Reis, R. E., S. O. Kullander \& C. J. Ferraris Jr. (Eds.). Check List of the Freshwater Fishes of South and Central America. Porto Alegre, Edipucrs, 729 p.

Machado-Allison, A., P. A. Buckup, B. Chernoff \& R. Royero. 1993. Las especies del genero Bryconops Kner, 1858 en Venezuela (Teleostei, Characiformes). Acta Biologica Venezuelica, 14: 1-20.

Machado-Allison, A., B. Chernoff \& P. A. Buckup. 1996. Bryconops humeralis y B. vibex, dos nuevas especies del genero Bryconops Kner (1858) para Venezuela. Acta Biologica Venezuelica, 16: 43-58.

Malabarba, L. R. \& V. A. Bertaco. 1999. Description of a new species of Heterocheirodon Malabarba (Teleostei: Characidae: Cheirodontinae: Cheirodontini), with further comments on the diagnosis of the genus. Comunicações do Museu de Ciências e Tecnologia da PUCRS, Série Zoologia, 12: 83-109.

Malabarba, L. R. \& S. H. Weitzman. 2003. Description of a new genus with six new species from southern Brazil, Uruguay and Argentina, with a discussion of a putative characid clade (Teleostei: Characiformes: Characidae). Comunicações do Museu de Ciências e Tecnologia da PUCRS, Série Zoologia, 16: 67-151.

Mirande, J. M. 2010. Phylogeny of the family Characidae (Teleostei: Characiformes): from characters to taxonomy. Neotropical Ichthyology, 8: 385-568.

Taylor, W. R. \& G. C. van Dyke. 1985 Revised procedures for staining and clearing small fishes and other vertebrates for bone and cartilage study. Cybium, 9: 107-119.

Submitted February 14, 2011

Accepted June 16, 2011

Published September 16, 2011 